\title{
Analisis Intensitas Radiasi Matahari di Manado dan Maros
}

\author{
Listya Dewi Rifaia,b*, Seni H. J. Tongkukuta, Slamet Suyitno Raharjob \\ aJurusan Fisika, FMIPA, Unsrat, Manado \\ bBadan Meteorologi Klimatologi dan Geofisika
}

\begin{tabular}{l}
\hline K A T A K U N C I \\
\hline Intensitas radiasi matahari \\
Deklinasi \\
Curah hujan
\end{tabular}

\begin{tabular}{l}
\hline K E Y W O R D S \\
\hline Solar Radiation intensity \\
Declination \\
Precipitation
\end{tabular}

AVAILABLE ONLINE 25 Februari 2014

\begin{tabular}{l} 
A B S T R A K \\
Telah dilakukan analisis intensitas radiasi matahari di Manado dan \\
Maros dengan menganalisis pola grafik intensitas radiasi matahari \\
terhadap sudut deklinasi matahari. Faktor pengaruh atmosfer dianalisis \\
dari pola intensitas radiasi matahari terhadap curah hujan dengan metode \\
regresi linear sederhana pada kedua daerah penelitian. Hasil yang \\
diperoleh berupa nilai intensitas radiasi matahari di Maros lebih tinggi \\
dibandingkan Manado sepanjang tahun, dengan Maros 133.121 \\
gram.cal/cm², dan Manado 117.289 gram.cal/cm². Penerimaan \\
intensitas radiasi matahari di Manado dan Maros dipengaruhi oleh \\
intensitas curah hujan di kedua daerah, yaitu kenaikan curah hujan \\
menurunkan intensitas radiasi matahari, disamping dipengaruhi oleh \\
kondisi geografi lokal dan faktor tutupan awan. \\
A B S T R A C T \\
An analysis of solar radiation intensity in Manado and Maros had \\
been performed by analyzing the chart pattern of the solar radiation \\
intensity against angle of solar declination. The effect of atmosphere was \\
analyzed using a simple linear regression method from the solar radiation \\
intensity pattern against the precipitation at the two areas. The results \\
showed that the solar radiation intensity value in Maros was higher than \\
that in Manado throughout the year, which were 133.121 gram.cal/cm ${ }^{2}$ in \\
Maros and 117.289 gram.cal/cm ${ }^{2}$ in Manado. The solar radiation intensity \\
in Manado and Maros was influenced by precipitation intensity in both \\
regions, that was the increasing precipitation intensity decreased the solar \\
radiation intensity, and by local geography and cloud factor. \\
\hline
\end{tabular}

\section{Pendahuluan \\ Posisi matahari dan kedudukan wilayah di permukaan bumi memberikan pengaruh nyata terhadap potensi radiasi matahari pada suatu wilayah. Potensi ini akan berubah tiap waktu, tergantung dari kondisi atmosfer, posisi (garis lintang), serta waktu (jumlah hari dalam tahun dan lama penyinaran matahari dalam satu hari) (Septiadi et al., 2009) [2]. Informasi mengenai ketersediaan energi matahari merupakan hal yang penting dalam rangka mendukung usaha pemanfaatan energi matahari seperti sistem}

pemanfaatan energi matahari sebagai energi listrik alternatif (photovoltaic/PV, solar concentrator, solar collector), desain arsitektur atau kenyamanan termal bangunan, dan lain-lain (Mubiru, 2008) [1].

Mengacu pada faktor posisi (garis lintang) akan dilakukan analisis intensitas radiasi matahari di dua lokasi berbeda di Indonesia yaitu Manado pada 1,51으 dan Maros pada 4,99 $\mathrm{LS}$. Faktor pengaruh atmosfer dianalisis dari hubungan curah hujan di Manado dan Maros dengan intensitas radiasi matahari. Menurut Panjaitan tahun 2011 [3], semakin banyak kandungan air di awan, maka nilai albedo (nilai yang menunjukkan ketebalan atau 
kandungan air pada awan) semakin tinggi. Nilai albedo yang kecil akan memberikan intensitas radiasi matahari yang besar, sedangkan nilai albedo yang besar akan memberikan intensitas radiasi matahari yang kecil. Dianalogikan bahwa jumlah curah hujan sebanding dengan lamanya tutupan awan yang menghalangi sinar matahari dan jumlah molekul air yang akan menyerap radiasi matahari di atmosfer. Penelitian tentang intensitas radiasi matahari di Manado dan Maros diharapkan dapat dimanfaatkan sebagai bahan pertimbangan pemanfaatan energi alternatif.

\section{Metode}

Metode yang dilakukan pada penelitian ini meliputi pengumpulan data intensitas radiasi matahari bulanan dan curah hujan bulanan di kedua titik penelitian selama 3 tahun terakhir (2010 sampai 2012), serta data deklinasi matahari. Datadata tersebut diolah dan dibuat grafik pola intensitas radiasi matahari bulanan, curah hujan bulanan, dan deklinasi matahari. Selanjutnya dilakukan analisis pada pola grafik intensitas radiasi matahari masing-masing daerah penelitian berdasarkan pola deklinasi matahari. Tahap terakhir adalah menganalisis pola grafik intensitas radiasi matahari masing-masing daerah penelitian terhadap pola curah hujan dengan metode regresi linear.

\section{Hasil dan Pembahasan}

\subsection{Pola Intensitas Radiasi Matahari Terhadap Deklinasi Matahari}

Data intensitas radiasi matahari pada masingmasing koordinat lintang penelitian berbeda (Manado pada $1,51^{\circ} \mathrm{LU}$ dan Maros pada 4,99 LS) digrafikkan bersama dengan deklinasi matahari tahunan. Data deklinasi matahari disajikan dalam bentuk gambar grafik untuk melihat perubahan posisi matahari terhadap lintang di permukaan bumi dari $23,5^{\circ}$ LS ke $23,5^{\circ}$ LU dan kembali ke $23,5^{\circ}$ LS selama satu tahun. Data deklinasi matahari digrafikkan bersama dengan data intensitas matahari bulanan rata-rata di Manado dan Maros dari Januari hingga Desember, untuk memperlihatkan perubahan intensitas radiasi matahari mengikuti perubahan posisi matahari (Gambar 1).

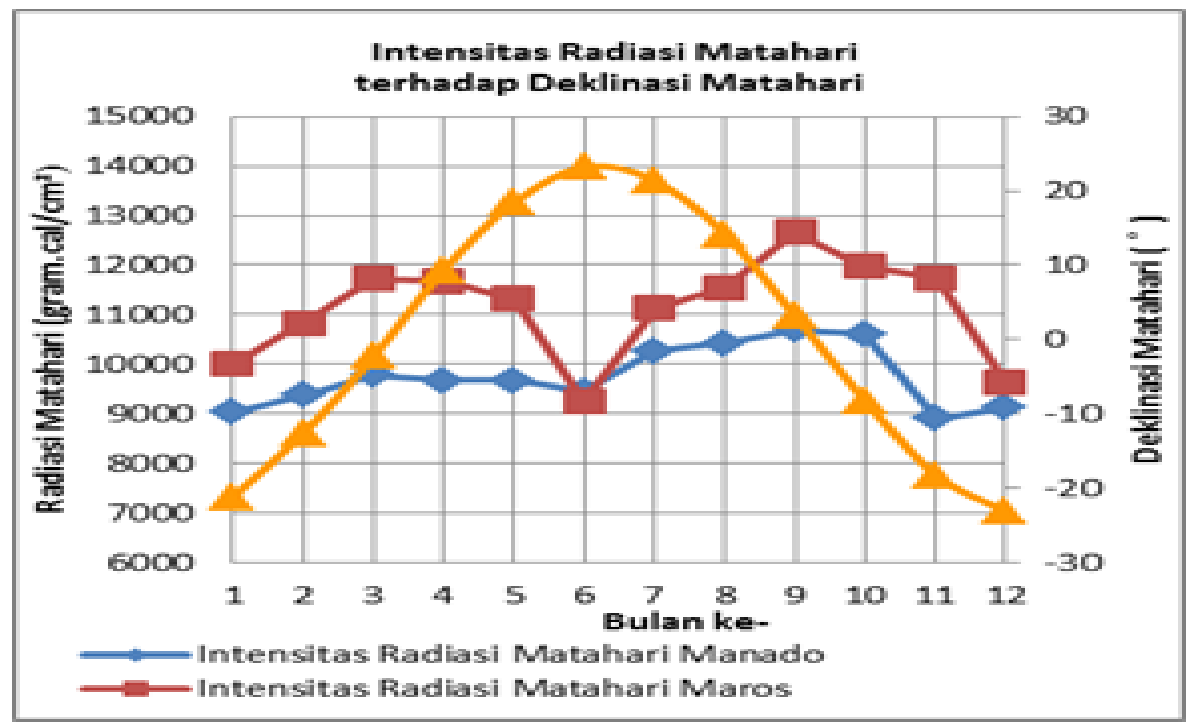

Gambar 1. Pola intensitas radiasi matahari terhadap pola deklinasi matahari di Manado dan Maros.

Gambar 1 menunjukkan bahwa dari bulan Januari sampai Desember intensitas radiasi matahari bervariasi mengikuti posisi matahari (deklinasi matahari) terhadap ekuator. Saat matahari menjauhi ekuator pada bulan Maret sampai Juni bersamaan nilai intensitas radiasi matahari di kedua tempat ikut menurun, sebaliknya saat posisi matahari mendekati ekuator pada bulan Juni sampai September bersamaan nilai intensitas radiasi matahari ikut naik. Untuk kedua daerah penelitian mempunyai pola yang cenderung sama.

Tampak pola intensitas radiasi matahari di Manado dan Maros mempunyai bentuk yang cenderung sama, akan tetapi Maros mempunyai nilai intensitas radiasi matahari yang lebih besar. Dengan demikian Maros memiliki potensi lebih besar dalam pemanfaatan energi matahari yang didukung oleh intensitas radiasi matahari total sepanjang tahun yaitu 133,518 gram.cal/ $\mathrm{cm}^{2}$, dibandingkan dengan Manado intensitas radiasi matahari total yaitu 117,026 gram.cal/ $\mathrm{cm}^{2}$.

\subsection{Analisis Pola Intensitas Radiasi Matahari di Manado dan Maros}

Menurut Lakitan (1994) [4], kelembapan udara berbanding lurus dengan ketinggian tempat, semakin rendah suatu tempat maka suhu ditempat tersebut akan semakin tinggi dan kelembapan udara semakin rendah. Suhu udara yang tinggi akan menyebabkan presipitasi (pengembunan) molekul air yang dikandung udara, sehingga muatan air dalam udara menurun.

Hal di atas berkaitan dengan hasil ketika faktor ketinggian tempat di Maros yang lebih rendah 
menyebabkan kelembapan udara menjadi rendah, sehingga muatan air dalam udara yang berpotensi menyerap radiasi matahari menurun sehingga jumlah intensitas radiasi matahari yang diterima lebih besar dalam setahun dengan selisih sekitar $16.491,8$ gram.cal/ $\mathrm{cm}^{2}$ dibanding Manado. Hal lain yang ikut menunjang adalah keadaan lingkungan Maros yang umumnya berupa daerah dataran sehingga hambatan angin lebih sedikit yang berakibat pada kondisi udara yang lebih kering sehingga kuantitas intensitas radiasi matahari yang diterima menjadi lebih banyak dibandingkan Manado yang berada pada ketinggian lebih tinggi, berbukit, dan bergunung.

\subsection{Intensitas Radiasi Matahari di Manado dan Maros dan Hubungannya dengan Curah Hujan}

Penguapan yang menghasilkan awan dan curah hujan yang termasuk dalam faktor efek atmosfer akan menyediakan uap air yang cukup di udara dan akan menyerap intensitas radiasi matahari. Sehubungan dengan kondisi tersebut akan dianalisis hubungan antara curah hujan dengan intensitas radiasi matahari di dua lokasi berbeda yaitu Manado dan Maros. Data curah hujan Manado dan Maros dibuat grafik bersama-sama dengan intensitas radiasi matahari dan sudut deklinasi matahari (Gambar 2).

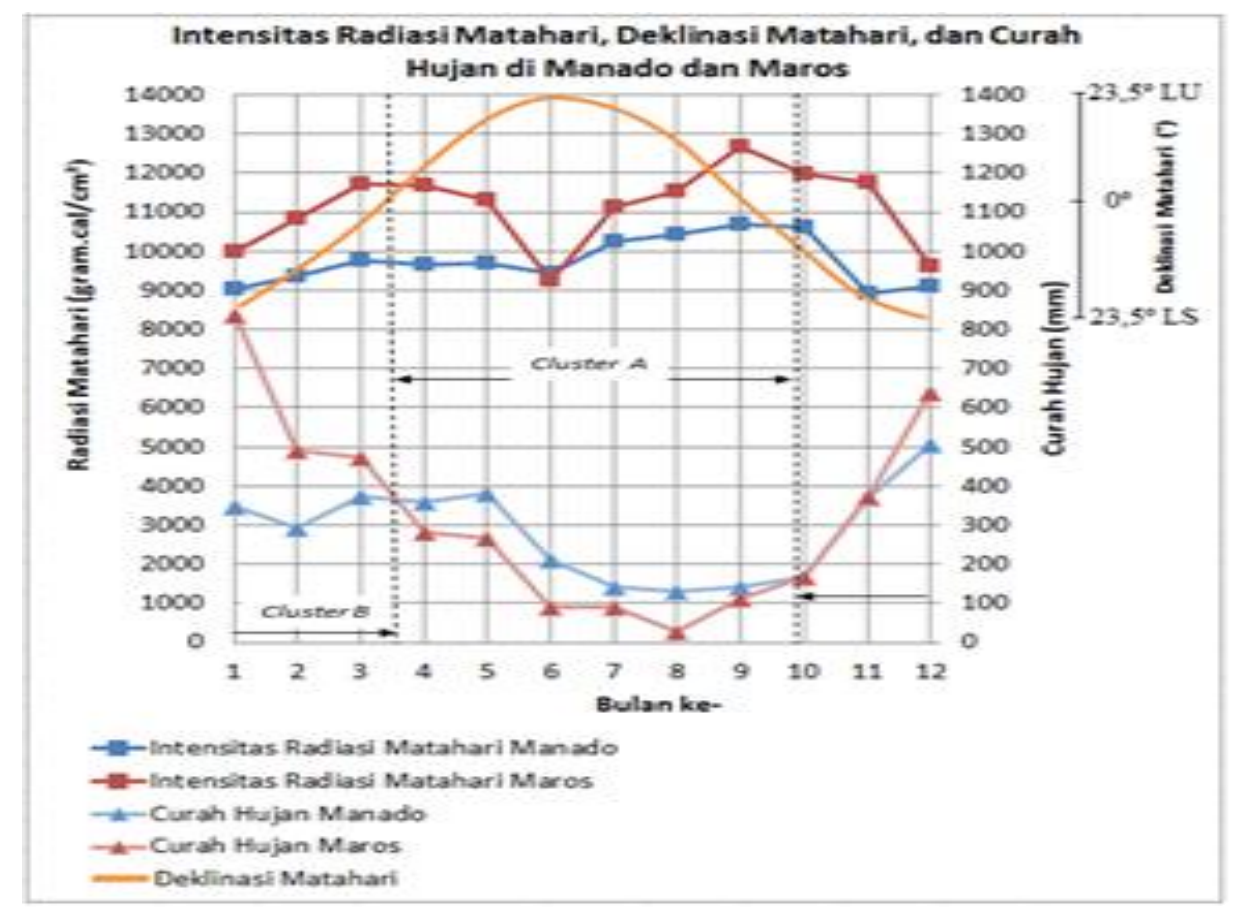

Gambar 2. Pola intensitas radiasi matahari, deklinasi matahari, dan curah hujan di Manado dan Maros.

Gas tertentu, terutama ozon $\left(\mathrm{O}_{3}\right)$, karbon dioksida $\left(\mathrm{CO}_{2}\right)$, dan uap air $\left(\mathrm{H}_{2} \mathrm{O}\right)$, memiliki daya serap yang sangat tinggi (Sekuler dan Blake, 1985) [5]. Asumsi awal dalam penulisan ini bahwa adanya awan yang selanjutnya mengakibatkan pembetukan tetesan air atau curah hujan dapat menjadi salah satu faktor penyerap radiasi matahari di atmosfer karena adanya uap air $\left(\mathrm{H}_{2} \mathrm{O}\right)$.

Pada cluster A, intensitas radiasi matahari di Maros lebih tinggi daripada intensitas radiasi matahari di Manado berhubungan dengan curah hujan di Maros lebih rendah daripada curah hujan di Manado. Keadaan tersebut menunjukkan hubungan yang sesuai dengan asumsi awal, yaitu curah hujan yang rendah akan mengakibatkan intensitas radiasi matahari yang tinggi.

Pada cluster B, asumsi curah hujan yang lebih tinggi akan memberikan intensitas radiasi matahari yang lebih rendah tidak terpenuhi.
Jika dihubungkan dengan deklinasi matahari, pada cluster $\mathrm{B}$ intensitas radiasi matahari dipengaruhi oleh posisi matahari yang sedang berada di belahan bumi Selatan sehingga intensitas radiasi matahari di Maros akan lebih tinggi walaupun dengan jumlah curah hujan yang lebih tinggi. Faktor lainnya seperti durasi dan banyaknya tutupan awan di kedua daerah penelitian dapat ikut mempengaruhi.

\subsection{Analisis Regresi Hubungan Curah Hujan dan Intensitas Radiasi di Manado dan Maros}

Gambar 3 menunjukkan pengaruh curah hujan bulanan terhadap intensitas radiasi matahari selama 3 tahun dihitung dan dijelaskan secara regresi linear sederhana. Metode regresi linear dilakukan dengan mengelompokkan bulan-bulan saat matahari berada di belahan bumi Utara sekitar April sampai dengan September, dan saat matahari di belahan bumi Selatan sekitar Oktober sampai dengan Maret. 


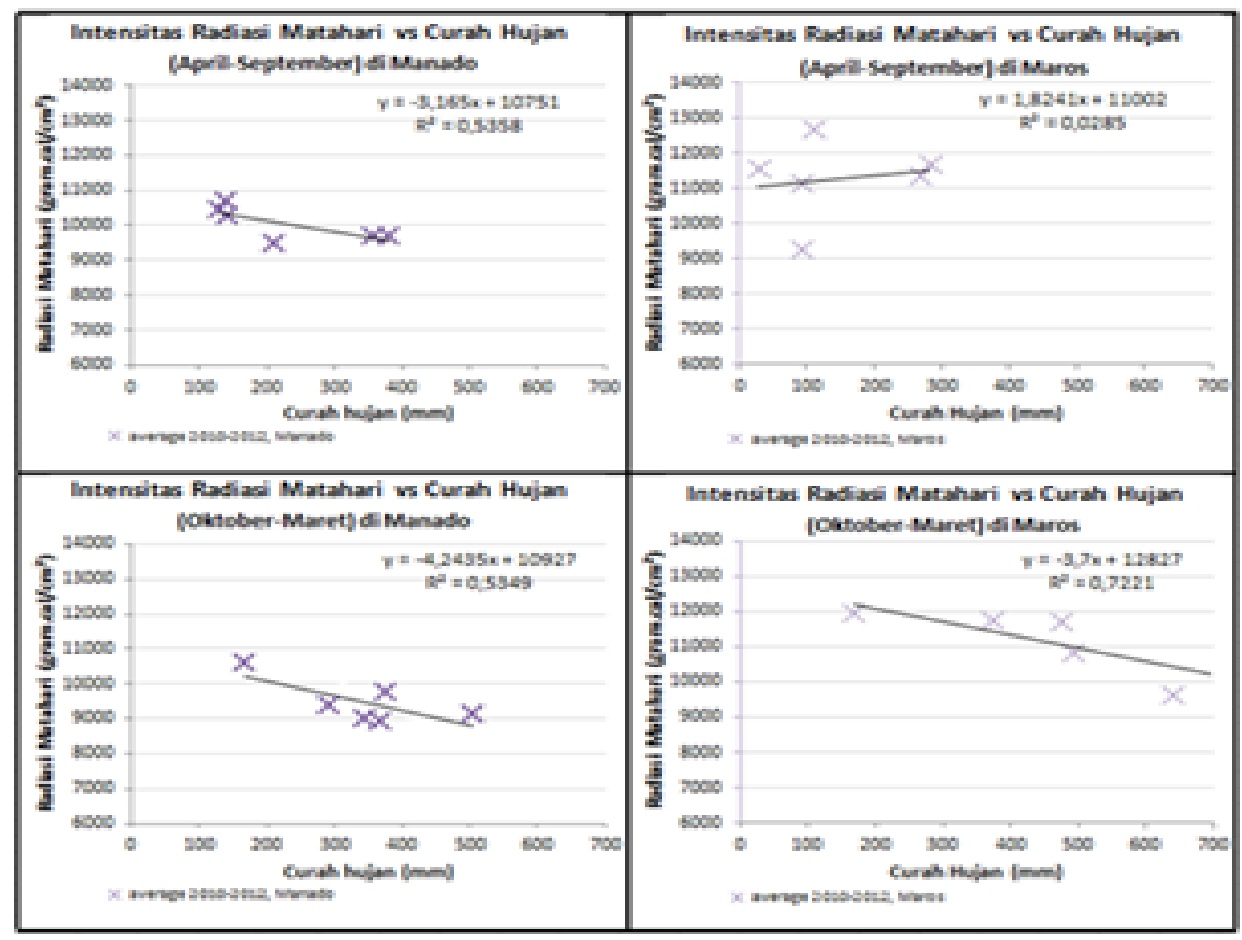

Gambar 3. Grafik pengujian system keseluruhan.

Di Maros penurunan curah hujan tidak menaikkan intensitas radiasi matahari pada bulan April sampai dengan Juni, tetapi penurunan curah hujan pada bulan Juni sampai Agustus, tampak mulai menaikkan lagi intensitas radiasi matahari pada bulan tersebut di kedua lokasi. Selanjutnya kenaikan curah hujan pada bulan September juga mulai menurunkan intensitas radiasi matahari pada bulan tersebut. Dengan demikian, anomali penurunan curah hujan yang tidak menaikkan intensitas radiasi matahari hanya terjadi pada bulan April sampai dengan Juni. Di Maros anomali tersebut terjadi karena pada bulan April sampai Juni sudut deklinasi matahari sedang menuju ke Utara menjauhi lokasi Maros yang menyebabkan intensitas radiasi matahari menurun meskipun curah hujan juga sedang turun.

Analisis regresi linear tersebut menunjukkan bahwa pada kedua daerah penelitian curah hujan yang makin tinggi secara signifikan menurunkan intensitas radiasi matahari yang diterima disamping faktor posisi terhadap deklinasi matahari ikut mempengaruhi

\section{Kesimpulan}

1. Pola perubahan intensitas radiasi matahari di kedua lokasi dipengaruhi oleh deklinasi matahari dengan pola intensitas radiasi matahari mengikuti pergerakan semu matahari. Intensitas radiasi matahari di Maros lebih besar dibandingkan Manado, dengan nilai intensitas radiasi matahari rata-rata sepanjang tahun untuk Maros 133.518 gram.cal/ $\mathrm{cm}^{2}$, sedangkan Manado 117.026 gram.cal/ $\mathrm{cm}^{2}$.

2. Pada kedua daerah penelitian, umumnya curah hujan yang makin tinggi secara signifikan menurunkan intensitas radiasi matahari. Hal ini karena curah hujan yang tinggi menunjukkan kandungan uap air yang menyerap intensitas radiasi matahari di udara cukup tinggi.

\section{Daftar Pustaka}

[1] Mubiru, J., and Banda, E. J. K. B. 2008. Estimation of Monthly Average Daily Global Solar Irradiation Using Artificial Neural Network. J. Solar Energy. 82: 181 -187.

[2] Septiadi, D., Nanlohy, P., Souissa, M., dan Rumlawang, F. Y. 2009. Proyeksi Potensi Energi Surya sebagai Energi Terbarukan (Studi Wilayah Ambon dan Sekitarnya). Jurnal BMKG Vol.10 Nomor 1 Juli 2009. Jakarta: BMKG.

[3] Panjaitan, A. L. 2011, Estimasi Energi Radiasi Matahari Bulanan dan Tahunan dengan Model Solar Energy-Air Temperature. Bandung: Institut Teknologi Bandung.

[4] Lakitan, B. 1994. Dasar Klimatologi. PT. Ragagrafindo Persada. Jakarta.

[5] Sekuler, R., and Blake R. 1985. Perception. New York: Alfred A. Knopf Inc. 